\title{
A NATUREZA DE JUS COGENS DO PRINCÍPIO DO NON- REFLOULEMENT E SUAS CONSEQUENCIAS NO DIREITO INTERNACIONAL DOS REFUGIADOS
}

\author{
THE JUS COGENS NATURE OF THE NON-REFLOULEMENT PRINCIPLE AND ITS \\ CONSEQUENCES IN INTERNATIONAL REFUGEE LAW
}

Debora Markman

\begin{abstract}
Mestranda em Direito pela Universidade Metodista de Piracicaba (UNIMEP); Especialista em Direito do Trabalho, Direito Previdenciário e Direito Constitucional pela Faculdade Dom Alberto; Graduada em Direito pela Universidade Presbiteriana Mackenzie (UPM);
\end{abstract} Email: deboramark@icloud.com

\section{Mirta Gladys Lerena Manzo de Misailidis}

Doutora em Direito das Relações Sociais pela Pontifícia Universidade Católica de São Paulo (PUC-SP); Professora do Programa de Pós-graduação em Direito da Universidade Metodista de Piracicaba (UNIMEP).

Email:mglmanzo@unimep.br

Recebido em: 01/11/2018

Aprovado em: 01/03/2019

RESUMO: O objetivo da presente pesquisa é, por meio de pesquisa bibliográfica e documental, trabalhar o princípio do non-refoulement e as consequências interpretativas de sua condição de norma de jus cogens no contexto do direito internacional dos refugiados. Referido princípio proíbe que o Estado no qual o requerente do status de refugiado se encontre seja devolvido ao país no qual se encontra ameaçado, apesar, até mesmo, de sua entrada irregular. É uma norma de jus cogens, vinculante e imodificável. O presente estudo é justificável pela crescente importância de se proteger os refugiados no contexto internacional. Concluiu-se que a natureza de jus cogens do princípio do non-refoulement faz com que tenha uma incidência quase absoluta, que faz com que as limitações do Art. 33 (2) da Convenção de 1951 caiam por terra.

Palavras-chave: Princípio do non-refoulement; Norma de jus cogens; Direito Internacional dos Refugiados.

ABSTRACT: The aim of the present research is, through bibliographical and documentary research, to work the principle of non-refoulement and the interpretative consequences of its condition of jus cogens norm in the context of international refugee law. Such a principle prohibits the State in which the applicant for refugee status is to be returned to the country in which he or 
she is threatened, even though it may have been irregularly entered. It is a norm of jus cogens, binding and unmodifiable. This study is justified by the growing importance of protecting refugees in the international context. It was concluded that the nature of jus cogens from the principle of non-refoulement causes it to have an almost absolute incidence, which causes the limitations of Art. 33 (2) of the 1951 Convention to fall to the ground.

Keywords: Non-refoulement principle; Jus cogens rule; International Refugee Law.

SUMÁRIO: Introdução; 1 O Direito Internacional dos Refugiados; 1.1 Breve escorço histórico; 1.2 Autonomia e sistemática; $1.3 \mathrm{O}$ conceito de refugiado; $1.4 \mathrm{O}$ temor de perseguição; $2 \mathrm{O}$ Princípio do Non-Refoulement; 2.1 Conceito e sistemática; $2.2 \mathrm{O}$ princípio do non-refulement como norma de jus cogens; 2.3 A (in)existência de exceções ao non-refoulement; Considerações Finais; Referências.

\section{INTRODUÇÃO}

Os movimentos migratórios resultantes de conflitos armados, questões ambientais e sistemáticas violações aos direitos humanos forçaram o desenvolvimento de um ramo específico do direito internacional, que tem sido chamado de direito internacional dos refugiados.

Referida divisão do direito internaciona público tem princípios próprios, aplicáveis no concernente às situações que envolvem, especificamente, as pessoas que requerem a proteção conferida pelo status de refugiado. Dentre esses princípios, encontram-se, como suas bases nterpretativas, a não-discriminação e o non-refoulement.

O princípio do non-refoulement (ou não expulsão) proíbe que o Estado no qual o pleiteante do status de refugiado se encontre possa devolvê-lo ao país no qual se encontra ameaçado quanto a seus direitos humanos, mesmo que sua entrada tenha sido irregular. Trata-se de uma norma de jus cogens e, portanto, vinculante e praticamente intangível.

Nesse sentido, o objetivo do presente trabalho é, por intermédio de pesquisa bibliográfica e documental, estudar o princípio do non-refoulement, bem como das consequências interpretativas da assunção de sua condição de norma de jus cogens no que concerne ao sistema do direito internacional dos refugiados.

O trabalho foi dividido em duas partes: o direito internacional dos refugiados, sua história, sua autonomia, sua sistemática e os conceito de refugiado e de temor de perseguição; e o princípio do non-refoulement, seu conceito, sua sistemática, sua natureza de jus cogens e as consequências dessa caracterização.

Justifica-se o presente estudo, em decorrência da crescente importância que a proteção aos refugiados tem alcançado no âmbito internacional. Concluiu-se que a natureza de jus cogens do princípio do non-refoulement faz com que tenha uma incidência quase absoluta, fazendo com que as limitações constantes do Art. 33 (2) da Convenção de 1951 caiam por terra.

\section{O DIREITO INTERNACIONAL DOS REFUGIADOS}

Ao lado direito internacional dos direitos humanos e do direito internacional humanitário, o direito internacional dos refugiados, em decorrência de seus desenvolvimentos 
históricos e teóricos, alçou autonomia principiológica, ainda subordinado, todavia, ao direito internacional e vinculado aos fundamentos das demais vertentes.

De modo a que seja possível trabalhar, com propriedade, essa principiologia específica, faz-se necessário estudar questões históricas relacionadas à temática, desde suas origens até a atualidade mais próxima, bem como sua autonomia e seus conceitos basilares, especificamente, as definições relacionadas aos refugiados e à perseguição.

\subsection{Breve escorço histórico}

Apesar de as origens da temática datarem de séculos atrás, em termos históricos, o direiro dos refugiados apenas recentemente encontrou tratamento formal pelo direito internacional, o que se deu, especialmente, em decorrência dos resultados nefastos das duas guerras mundiais.

Antes do Século XX, não haviam regras internacionais voltadas à proteção dos refugiados, que dependiam apenas da generosidade (muitas vezes inexistente) das leis nacionais (PEREIRA, 2014, p. 13). No Século XVII, na Europa, o asilo foi laicizado e transferido o poder de sua concessão aos Estados Nacionais (RAMOS, 2016, p. 87).

No Século XVIII, foi pela primeira vez inserido no art. 120 da Constituição francesa de 1793, que previa asilo aos estrangeiros exilados em virtude da luta pela liberdade (RAMOS, 2016, p. 87).A Cruz Vermelha, criada e idealizada por Henri Dunant, em 1863, teve grande importância no amparo às pessoas nos conflitos entre as nações (PEREIRA, 2014, p. 13).

Foi a primeira organização humanitária voltada à proteção e à assistência às vítimas da guerra e de outras situações. Consagrou-se a natureza constumeira do amparo às pessoas em situação de debilidade (PEREIRA, 2014, p. 13). Nota-se, desde o início, a característica de jus cogens à proteção aos direitos do refugiado.

O Tratado sobre o Direito Penal Internacional de Montevidéu, de 1889, no entanto, foi o primeiro a positivar o instituto do asilo (ALMEIDA, 2015, p 54). Durante algumas décadas, todavia, tratou-se da única disposição internacional de relevo que se colocava a favor daqueles que tinham necessidade de serem asilados.

Finda a Primeira Grande Guerra, o número de pessoas que não eram mais bem-vindas ou assimiladas por parte alguma aumentou intensamente. Sem lar, cidadania ou direitos, deslocaramse 1.500.000 russos brancos, 700.000 armênios, 500.000 búlgaros, 1.000 .000 de gregos e milhares de alemães, húngaros e romenos. (AGAMBEN, 1996)

Além dessas gigantescas massas migratórias, cerca de $30 \%$ das populações dos novos organismos estatais criados por tratados de paz (Iugoslávia e Tchecoslováquia, v.g.), constituídas de minorias, tiveram de ser tuteladas por meio de uma série de tratados internacionais, chamados Minority Treaties (AGAMBEN, 1996).

Vários Estados europeus começaram a introduzir leis de desnaturalização dos seus próprios cidadãos, a exemplo da França, em 1915, da URSS, em 1921 e da Bélgica, em 1922 (AGAMBEN, 1996). Note-se, portanto, que a temática dos refugiados alcançou um point of no return, de modo que sua efetiva regulamentação passou a ser inevitável.

Somente após o estabelecimento da Sociedade das Nações (ou Liga das Nações), em 1919, discutiu-se intensamente sobre o papel da comunidade internacional no adequado tratamento aos refugiados, especialmente após a Revolução Comunista na Rússia e as crises no antigo Império Otomano (RAMOS, 2016, p. 88).

Em 1921, o Conselho da Sociedade das Nações autorizou a criação de um Alto Comissariado para Refugiados, especificamente voltado ao tratamento dos refugiados russos. 
Após a constatação da existência de refugiados armênios na Grécia, porém, optou-se por uma definição abrangente e geral do mandato do Comissariado (RAMOS, 2016, p. 88).

Essa primeira fase da internacionalização da proteção aos refugiados foi caracterizada pela abordagem coletiva e geral dos refugiados, que consistia em qualificar o refugiado em função de sua pertença a um determinado grupo composto por refugiados e pela ênfase no repatriamento ou na inserção coletiva em um Estado de acolhida. (RAMOS, 2016, p. 89).

O Alto Comissariado foi, portanto, a primeira iniciativa formal acerca da temática, que resultou do trabalho de uma organização internacional que contava com diversas nações em sua composição. O trabalho iniciado pela Liga nesse sentido, surtiu efeitos no ordenamento internacional alguns anos depois.

O Dr. Fridtjof Nansen (1861-1930), delegado da Noruega na Liga das Nações, por seu trabalho humanitário, obteve o Prêmio Nobel da Paz, em 1923, em nome do Alto Comissariado para os Refugiados Russos (LOESCHER, 1993). Trata-se do idealizador do passaporte Nansen, um certificado de identidade e de viagem fornecido aos refugiados (ALMEIDA, 2015, p 78).

Foi a primeira tentativa de suprir a ausência de uma proteção jurídica nacional, por meio do documento jurídico que inspirou o estatuto do refugiado. Em $1^{\circ}$ de abril de 1931, foi estabelecida a primeira organização internacional especificamente voltada aos refugiados: a Nansen International Office for Refugees (ALMEIDA, 2015, p 78-79).

O Escritório Internacional, portanto, institucionalizou a ideia iniciada pela Liga, a partir do Alto Comissariado, passando a promover tratamento jurídico internacional específico aos refugiados, todavia, ainda por intermédio da abordagem coletiva e geral que, por sua vez, demonstrou sua necessidade nas décadas seguintes.

De 1930 a 1947, em decorrência das Guerras Mundiais, aumentou significativamente o fluxo de refugiados e apátridas pelo mundo. A Segunda Guerra Mundial produziu cerca de 40 milhões de refugiados, o que tornou necessária a criação de uma instituição de "[...] renovadas ferramentas para a proteção de seus direitos" (PEREIRA, 2014, p. 15).

Nesse sentido, a Segunda Grande Guerra dilacerou a comunidade dos países europeus, fazendo com que inflação, desemprego e guerras civis sobreviessem e se alastrassem durante os anos seguintes ao seu término, situação que resultou na migração de imensos contingentes humanos, que não eram bem-vindos e não podiam ser assimilados (ARENDT, 1989, p. 300).

Fora de seu país de origem, encontravam-se sem lar. Deixando seu Estado, tornavam-se apátridas. Perdendo seus direitos humanos, perdiam todos os demais. Eram o refugo da terra. Por isso é que a real importância dos tratados sobre minorias não estava em sua aplicação prática, mas, sim, em serem garantidos pela Liga das Nações (ARENDT, 1989, p. 308).

O reconhecido de que milhões de pessoas viviam fora da proteção legal, necessitando de garantias adicionais por parte de uma entidade externa e a admissão de que este estado de coisas era permanente, fez com que os tratados fossem necessários para a criação de um modus vivendi duradouro (ARENDT, 1989, p. 308).

Os fluxos migratórios produzidos pela Segunda Guerra Mundial, resultante do massacre físico, econômico e social de várias classes de pessoas, fizeram com que o direito internacional tivesse que se reinventar em sua integralidade, especialmente no que concerne ao tratamento dos refugiados.

O Escritório Nansen e o Alto Comissariado para Refugiados encerraram suas atividades em 30 de setembro de 1938, com a criação do Alto Comissariado da Sociedade das Nações para os Refugiados. Começou a fase de qualificação individual (1938-1952), cujo principal objetivo era operar com uma definição ampla de refugiado (ALMEIDA, 2015, p. 80). 
A temática passou a ser tratada pelo Comitê Intergovernamental e pela United Nations Relief and Rehabilitation Administration (UNRRA), criada em 1943 (ALMEIDA, 2015, p 83). Note-se, portanto, que o padrão de tratamento foi modificado, do coletivo e geral para o individual, em decorrência do reconhecimento das diferenças entre os grupos migratórios.

Entre 1944 e 1945, a UNRRA assistiu, emergencial e temporariamente, milhões de pessoas, seguindo o padrão estabelecido no intervalo entre as Guerras. Não era apenas de uma organização para refugiados, pois auxiliou todos aqueles que foram deslocados pela guerra e, em alguns casos, refugiados que padeciam de temores políticos (LOESCHER, 1993, p. 43).

Após o ano de 1945, contudo, o direito internacional dos direitos humanos passaria por uma revolução paradigmática, nos contextos social, jurídico e administrativo, modificação que ocorreu, em especial, como resultado dos horrores experimentados no contexto da Segunda Grande Guerra.

Em junho de 1945, com a Conferência de São Francisco, definiu-se e criou-se a Organização das Nações Unidas, impulsionada pela Carta das Nações Unidas, "[...] documento que delineia e estabelece os princípios e prerrogativas do órgão internacional, orientados pela igualdade soberana entre os Estados" (PEREIRA, 2014, p. 15).

A Carta das Nações Unidos afirma que a função da ONU seria a promoção da paz mundial e dos direitos humanos e a resolução pacífica das controvérsias internacionais (PEREIRA, 2014, p. 15). Entre suas váras funções se encontrava a assistência social e jurídica aos refugiados (ALMEIDA, 2015, p. 86).

Após sua criação iniciou-se o debate para a institucionalização de um organismo que se dedicasse, exclusivamente, à temática dos refugiados. Em 31 de dezembro de 1946, com o fim da Sociedade das Nações, encerraram-se as atividades do Alto Comissariado da Sociedade das Nações para os Refugiados (ALMEIDA, 2015, p. 90).

Simultaneamente, foi estabelecida a Comissão Preparatória da Organização Internacional para os Refugiados (OIR) (PEREIRA, 2014, p. 15). Em 1948, a Declaração Universal dos Direitos Humanos impulsonou a denominada fase da qualificação individual dos refugiados, especialmente com o que dispunha em seu Art. 14¹ (RAMOS, 2016, p. 89).

A Assembleia Geral das Nações Unidas criou o Alto Comissionado das Nações Unidas para os Refugiados (ACNUR) por meio da Resolução no 319 (IV), de 3 de dezembro de 1949. Seu Estatuto foi aprovado em 14 de dezembro de 1950, pela Resolução 428 (V), iniciando suas atividades em $1^{\circ}$ de janeiro de 1951 (ALMEIDA, 2015, p 94).

Simultaneamente à criação do Alto Comissionado, sobreveio uma convenção internacional cujo objeto se voltava especificamente à questãos dos refugiados, e que trouxe princípios, direitos, prerrogativas e procedimentos relacionados à temática, assim como previu um marco jurídico específico.

A Convenção de Genebra de 1951, ouCarta dos Direitos dos Refugiados regulamenta sua situação jurídica em um marco migratório determinado, outorgando-lhes os direitos de residência, trabalho remunerado, propriedade, associação, acesso aos tribunais, educação, assistência social, documento de identidade e viagem (CUNHA, 2001, p. 476).

Em especial, a Convenção outorga-lhes o direito a não ser devolvido, contra sua vontade, a seu país de origem, no qual sua vida, liberdade e segurança estejam em perigo (CUNHA, 2001,

1“Art. 14. 1. Todo ser humano, vítima de perseguição, tem o direito de procurar e de gozar asilo em outros países. 2. Esse direito não pode ser invocado em caso de perseguição legitimamente motivada por crimes de direito comum ou por atos contrários aos objetivos e princípios das Nações Unidas” (ONU, 1948, n.p.). 
p. 476). Em seu artigo $1^{02}$, conceitua o status de refugiado para o Direito Internacional e o desenvolvimento dos aparatos para sua proteção (PEREIRA, 2014, p. 21).

O objetivo da Convenção foi proteger as pessoas perseguidas, ou seja, com bem fundado temor de perseguição no continente Europeu, em seu país de origem ou moradia habitual, em decorrência apenas dos eventos da Segunda Guerra Mundial, estabelecendo um critério limitador geográfico e espacial (PEREIRA, 2014, p. 21),

Note-se que essa disposição seria prejudicial ao futuro dos refugiados, tendo em vista que a Convenção não poderia ter suas disposições aplicadas a eventuais conflitos ou a novos fluxos migratórios de massa. Não bastasse, referido tratado previa a possibilidade de reserva injustificada e discricionária de parte dos Estados signatários.

Os Estados podiam estabelecer limitação geográfica, aplicando o Estatuto apenas em relação a eventos ocorridos na Europa. Em 1967 foi aprovado o Protocolo Adicional à Convenção sobre Refugiados, que suprimiu a limitação temporal. Em 1969, foi aprovada a Convenção da Organização da Unidade Africanasobre refugiados (RAMOS, 2016, p. 90-91).

Referida convenção, vigorante a partir de 1974, estabeleceu, pela primeira vez, a definição ampla de refugiado, que abrange todo aquele que, em decorrência de cenário de graves violações de direitos humanos, "[...] foi obrigado a deixar sua residência habitual para buscar refúgio" em outro Estado (RAMOS, 2016, p. 91).

A Declaração sobre a eliminação de todas as formas de intolerância e discriminação fundadas na religião ou nas convicções religiosas, de 1981, por meio de seu artigo $2^{\circ}$, $\$ 2^{\circ 3}$, estendeu ainda mais o conceito. Em 1984, essa definição ampla foi acolhida e ampliada pelo item 3 da Declaração de Cartagena. (RAMOS, 2016, p. 94).

Nesse sentido, o ACNUR é um órgão da ONU, diretamente vinculado à Assembleia Geral. Apesar de ter recebido mandato de três anos para reassentar 1.200.000 refugiados europeus após a Segunda Grande Guerra, teve suas competências prorrogadas várias vezes. A última prorrogação ocorreu em 1997 (ALMEIDA, 2015, p 102).

\footnotetext{
2“Art. $1^{\circ}$ - Definição do termo 'refugiado' A. Para os fins da presente Convenção, o termo 'refugiado' se aplicará a qualquer pessoa: 1) Que foi considerada refugiada nos termos dos Ajustes de 12 de maio de 1926 e de 30 de junho de 1928, ou das Convenções de 28 de outubro de 1933 e de 10 de fevereiro de 1938 e do Protocolo de 14 de setembro de 1939, ou ainda da Constituição da Organização Internacional dos Refugiados; [...] 2) Que, em consequiência dos acontecimentos ocorridos antes de $1^{\circ}$ de janeiro de 1951 e temendo ser perseguida por motivos de raça, religião, nacionalidade, grupo social ou opiniões políticas, se encontra fora do país de sua nacionalidade e que não pode ou, em virtude desse temor, não quer valer-se da proteção desse país, ou que, se não tem nacionalidade e se encontra fora do país no qual tinha sua residência habitual em conseqüência de tais acontecimentos, não pode ou, devido ao referido temor, não quer voltar a ele" (ONU, 1951, n.p.).

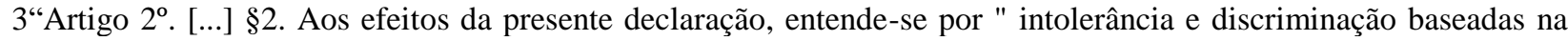
religião ou nas convicções" toda a distinção, exclusão, restrição ou preferência fundada na religião ou nas convicções e cujo fim ou efeito seja a abolição ou o fim do reconhecimento, o gozo e o exercício em igualdade dos direitos humanos e das liberdades fundamentais" (ONU, 1981, n.p.).

4"Terceira - Reiterar que, face à experiência adquirida pela afluência em massa de refugiados na América Central, se toma necessário encarar a extensão do conceito de refugiado tendo em conta, no que é pertinente, e de acordo com as características da situação existente na região, o previsto na Convenção da OUA (artigo 1, parágrafo 2) e a doutrina utilizada nos relatórios da Comissão Interamericana dos Direitos Humanos. Deste modo, a definição ou o conceito de refugiado recomendável para sua utilização na região é o que, além de conter os elementos da Convenção de $1951 \mathrm{e}$ do Protocolo de 1967, considere também como refugiados as pessoas que tenham fugido dos seus países porque a sua vida, segurança ou liberdade tenham sido ameaçadas pela violência generalizada, a agressão estrangeira, os conflitos internos, a violação maciça dos direitos humanos ou outras circunstâncias que tenham perturbado gravemente a ordem pública" (COLÓQUIO, 1984, n.p.).
} 
Apesar de ter sido criada no âmbito das Nações Unidas, logo após a Declaração Universal dos Direitos Humanos, a Convenção de 1951 trouxe princípios específicos, especialmente a cláusula do non-refoulement. Referidos princípios, todavia, não encontravam autonomia no concernente ao direito internacional público.

AConferência Internacional sobre Refugiados Centro-americanos (CIREFCA $)^{5}$, reconheceu a relação entre a observância das normas de direitos humanos, os movimentos de refugiados e os problemas de proteção, favorecendo e impulsionando a convergência entre as três vertentes da proteção internacional (RAMOS; RODRIGUES; ALMEIDA, 2011, p. 78).

ADeclaração de San José sobre os Refugiados e Pessoas Deslocadas (1994), afirmouque a violação dos direitos humanos é a principal causa da existência do deslocamento, e reconheceu as convergências entre os sistemas de proteção internacional, "[...] enfatizando os seus caracteres complementares" (RAMOS; RODRIGUES; ALMEIDA, 2011, p. 78).

As atribuições do ACNUR, mesmo após a queda do marco migratório determinado, permanecem, o que corrobora a autonomia princípiológica do direito internacional dos refugiados enquanto subdivisão do direito internacional público e sua sistematização com o direito internacional dos direitos humanos e o direito internacional dos refugiados.

\subsection{Autonomia e sistemática}

A eliminação do marco migratório determinado e o reconhecimento do princípio do nonrefoulement como jus cogens fizeram, produziram a autonomia interpretativa do direito internacional dos refugiados, separando-o do direito internacional dos direitos humanos e do direito internacional humanitário.

O Direito Internacional dos Direitos Humanos tem hermenêutica própria. Seus métodos interpretativos determinam sua autonomia e especificidade, sem, todavia, apartar-se do direito dos tratados, apesar de "reger relações jurídicas de natureza diversa" (TRINDADE, 2007, p. 287).

Por ter como objetivo a proteção do ser humano, abarca, também, o Direito Internacional Humanitário e o Direito Internacional dos Refugiados, vertentes que convergem para a realização do propósito comum de proteger o ser humano em tempos de paz e de conflito, em seu próprio país e alhures, em toda atividade humana (TRINDADE, 2007, p. 287).

As aproximações e convergências entre o Direito Internacional Humanistário e o Direito Internacional dos Refugiados têm contribuído a superação das compartimentalizações artificiais do passado e para o aperfeiçoamento da proteção internacional da pessoa humana, titular único dos direitos humanos, sob quaisquer circunstâncias (TRINDADE, 2007, p. 287).

A autonomia interpretativa dessa subdivisão do direito internacional público, não faz, porém, com que possa desobedecer os princípios gerais ou mesmo a Declaração Universal dos Direitos Humanos. Ocorre que suas especificidades corroboram uma independência hermenêutica limitada.

O Direito dos Refugiados se volta à proteção do ser humano em uma situação específica: a de sua saída do país de residência habitual, em decorrência de perseguição ou fundado temor de perseguição, por motivo odioso. Por isso é que as suas definições basilares devem ser buscadas no Direito Internacional dos Direitos Humanos (RAMOS, 2016, p. 93).

5Por meio dos documentos: Princípios e Critérios para a Proteção e Assistência aos Refugiados, Repatriados e Deslocados Centro-americanos em América Latina (1989); e Princípios e Critérios (1994) (RAMOS; RODRIGUES; ALMEIDA, 2011, p. 78). 
Essa independência parcial, contudo, não afasta a incidência de princípios específicos do direito internacional dos refugiados, situação que, novamente, confirma sua autonomia interpretativa, resultante, em especial, do fato de que protege pessoas e grupos de pessoas que se encontram em uma situação específica.

Os princípios basilares do Direito Internacional dos Refugiados são: anão discriminação; e o non-refoulement. Aquele retoma "[...] a ideia de que o refúgio é um instituto de solidariedade internacional e de proteção internacional da pessoa humana e que não pode ser aplicado de maneira política" (RAMOS; RODRIGUES; ALMEIDA, 2011, p. 172).

O princípio do non-refouement, objeto específico do presente trabalho, será retomado abaixo, no concernente aos seus conceitos basilares e à sua natureza de jus cogens. Faz-se imperioso, todavia, trabalhar o conceito de refugiado, indispensável no referente ao entendimento acerca do tema.

\subsection{0 conceito de refugiado}

O conceito de refugiado que consta da Declaração de Genebra de 1951 (Carta dos Direitos dos Refugiados), apesar da queda do marco migratório determinado, ainda mantém suas especificidades. Em decorrência delas, faz-se necessário estabelecer as diferenças existentes entre asilo, exílio e refúgio.

Desde o início dos tempos, há pessoas que, forçosamente, deixam sua terra natal em busca de proteção em um território estrangeiro. O asilo, existia na Grécia Antiga, surgido como uma instituição do Direito consuetudinário, que garantia ao estrangeiro a possibilidade de encontrar proteção fora de sua terra natal (ALMEIDA, 2015, p. 83).

Já o exilado é aquele que vive o exílio, distante de sua terra natal, tendo deixado-a de maneira voluntária ou forçosa: no primeiro caso, trata-se de um migrante; no segundo, é um exilado stricto sensu, caso seja recebido como qualquer qualquer estrangeiro, ou asilado, se receber proteção jurídica do país que o acolheu (ALMEIDA, 2015, p. 85).

Desse modo, entre o exilado stricto sensu e o asilado, a diferença é, justamente, o reconhecimento jurídico da existência de uma perseguição. No mesmo sentido, nada impede que um apátrida obtenha o status de refugiado, caso tenha sido forçado a deixar seu país em busca de proteção (ALMEIDA, 2015, p. 86).

Até a solicitação da concessão de refúgio, a pessoa é um "buscador de asilo" (asylum seeker). A partir da solicitação, passa a ser um solicitante do estatuto do refugiado. Caso receba esse estatuto, passa a ser um refugiado. Em todas as etapas do processo faz-se necessária a proteção, já que seus direitos estão na iminência de violação. (ALMEIDA, 2015, p. 86-87).

A definição expressa de "refugiado" que se encontra no Art. $1^{\circ}$ da Convenção de 1951 deixa explícita a relação existente entre odireito internacional dos refugiados e o direito internacional dos direitos humanos (ALMEIDA, 2015, p. 87), o que faz com que tenha nuances que vão além das disposições convencionais explícitas.

Além da proteção contra o regresso forçado ao país no qual sua vida, liberdade ou segurança estão ou podem estar em perigo, o refugiado precisa de um lugar no qual possa levar uma vida normal. Assim, o asilo está implícito na Convenção de 1951, que dispõe sobre o tratamento a ser dispensado pelos Estados aos refugiados (GALINDO VÉLEZ, 2011, p.181).

Ocorre que, mesmo que o asilo esteja implícito na Convenção, entraria em conflito com os conceitos de Estado e de soberania. Assim, a única maneira de alterar essa regra seria por meio de um tratado internacional com disposição exeplícita (GALINDO VÉLEZ, 2011, p.181). 
Como será estudado abaixo, porém, o fato de o princípio do non-refoulement ser uma norma de jus cogens faz com que seja desnecessária qualquer alteração convencional expressa. Não bastasse, existem diferenças procedimentais entre os institutos do asilo e do refúgio, que tornam impossível a confusão entre ambos.

É necessário que o refúgio seja concedido a partir de uma decisão fundamentada, passível de recurso. No caso de asilo, é possível que o requerimento seja feiro fora do território para o qual se solicitou a proteção, nas embaixadas ou consulados, que detêm imunidade de jurisdição (PEREIRA, 2014, p. 24).

No caso do refúgio, o requisito da extraterritorialidade (alienage) é indispensável, de modo que o solicitante, para que possa gozar o status de refugiado, deve requerê-lo após seu ingresso no país solicitado. Além disso, também são refugiado "[...] as pessoas deslocadas forçadamente dentro do seu próprio território de residência” (PEREIRA, 2014, p. 24-26).

Assim, todas as pessoas com fundado temor de perseguição podem receber proteção dentro do território onde há o conflito. A essas pessoas denomina-se deslocados internos, uma espécie dentro do gênero "refugiado" (PEREIRA, 2014, p. 26), conclusão que denota a ampliação interpretativa do conceito.

O refúgio é devido, portanto, na ausência de mecanismos internos para combater a perseguição, "tornando a vida do solicitante de refúgio impossível naquele Estado". Assim, a obstaculização do gozo e do exercício de direitos fundamentais ou o fundado temor de que isso ocorra caracteriza a condição jurídica de refugiado (RAMOS, 2016, p. 93-94).

Confirma-se, assim, certa interpenetração entre os três conceitos, especialmente entre o asilo e o refúgio.

$\mathrm{O}$ direito de refúgio e o de asilo são institutos aproximados, porém, não idênticos. A América Latina conhece o asilo desde o século XIX. Na X Conferência Interamericana de Caracas, de 1954, foram aprovadas duas convenções, uma sobre asilo diplomático e outra sobre asilo territorial (COMPARATO, 2017, p. 297).

O refúgio, por ser concedido em razão de perseguição religiosa, racial, de nacionalidade e de opinião política, “[...] é um instituto de proteção de minorias, no sentido que o vocábulo apresenta no artigo 27 do Pacto sobre Direitos Civis e Políticos"' (COMPARATO, 2017, p. 297). Outro conceito essencial ao direito internacional dos refugiados é a perseguição.

\subsection{0 temor de perseguição}

De conformidade com a sistemática internacional acerca do conceito de refugiado, faz-se desnecessária a comprovação cabal de uma efetiva situação de perseguição, maus tratos ou de violação individual de direitos humanos: basta o simples temor de perseguição, desde que seja bem fundado.

A dogmática jurídica internacional separando o bem fundado temor de perseguição em subjetivo e objetivo, bem como distinguindo as formas de análise do grau de temor para a concessão do status de refugiado. Nesse sentido, "[...] para ser considerado um refugiado, o bem fundado temor subjetivo é presumível” (PEREIRA, 2014, p. 21).

Presume-se que a pessoa detém, subjetivamente, o medo de regressar ao seu Estado ou residência de origem. Já o bem fundado temor objetivo deve ser minimamente comprovado pelo

6“Art. 27. Nos Estados em que haja minorias étnicas, religiosas ou lingüísticas, as pessoas pertencentes a essas minorias não poderão ser privadas do direito de ter, conjuntamente com outros membros de seu grupo, sua própria vida cultural, de professar e praticar sua própria religião e usar sua própria língua” (ONU, 1966, n.p.). 
solicitante de refúgio, porém, não de forma contundente, já que, muitas vezes, o solicitante sequer possui identificação documental (PEREIRA, 2014, p. 21).

Em caso de dúvida, concede-se o refúgio ao requerente. A decisão fica "[...] adstrita à sensibilidade da pessoa que terá contato com o solicitante de refúgio, por meio de entrevistas individuais, analisando se há algum conflito político ou social no país do qual o solicitante se retirou e se há coerência interna e não contradições nos seus dizeres" (PEREIRA, 2014, p. 22).

Apesar da subjetividade inerente à análise do pedido de refúgio baseado no bem fundado temor de perseguição, não se trata de uma atuação discricionária, já que se demanda um mínimo de objetividade no que concerne aos fundamentos do requerimento, especificamente no que concerne à situação jurídico-política do país de origem do requerente.

$\mathrm{Na}$ avaliação do fundamento do temor, deverá ser levada em conta a situação objetiva do país de origem e suas relações com o receio de perseguição alegado. É nesse ponto que surgirá o elemento subjetivo. Perseguição, é a ameaça à vida ou à liberdade do indivíduo, correspondente à iminênte violação de sua vida ou de sua liberdade (ALMEIDA, 2015, p. 97).

Comprova-se, assim, a objetividade limitada no concernente à análise do pedido de refúgio, já que a própria Convenção de Genebra de 1951 vincula o conceito de perseguição à existência objetivamente comprovável de ameaça ao indivíduo. Essa ameaça, porém, deve ser considerada inevitável.

Exsurge um juizo de possibilidade que sequer demanda a prova inevitabilidade da perseguição, mas apenas sua possibilidade, de modo que o fundado temor de perseguição é critério objetivo, a ser faticamente comprovado (RAMOS, 2016, p. 89). Superados esses conceitos basilares, passa-se ao estudo do princípio do non-refoulement.

\section{O PRINCÍPIO DO NON-REFOULEMENT}

De conformidade com o que foi observado acima, o non-refoulement é um dos dois princípios basilares do direito internacional dos refugiados, ao lado do princípio da nãodiscriminação. Em decorrência da autonomia interpretativa dessa repartição do direito internacional público, referido princípio alcança nuances amplas.

Não bastasse, a relevância hermenêutica do princípio faz com que seja uma norma de Direito Internacional geral, integrante do conjunto normativo que constrói o jus cogens, afirmação corroborada tanto pela doutrina internacionalista quanto por disposição convencional expressa.

\subsection{Conceito e sistemática}

Assim como boa parte do direito internacional dos direitos humanos, a simples existência de um direito internacional dos refugiados já foi considerada uma afronta, bem como uma ameaça ao conceito clássico de soberania estatal, de modo que seu desenvolvimento levou várias décadas até alcançar sua dimensão atual.

O princípio do non-refoulement ou "não-repulsão" surgiu em meados da década de 1930. Somente no período pós-Segunda Guerra Mundial é que a não-devolução foi configurada como princípio básico do direito internacional dos refugiados, nos termos do Art. 33 (1) da Convenção Relativa ao Estatuto dos Refugiados, de 19517. (TRINDADE, 2011, p. 292)

7“Art. 33 - Proibição de expulsãoou de rechaço. 1. Nenhum dos Estados Contratantes expulsará ou rechaçará, de maneira alguma, um refugiado para as fronteiras dos territórios em que a sua vida ou a sua liberdade seja ameaçada 
Se encontra no Art. $3^{\circ}$ do protocolo 4 à Convenção Europeia dos Direitos Humanos, $(1950)^{8}$ e no Art. 22(8) da Convenção Americana sobre Direitos Humanos (1969) ${ }^{9}$. Foi consagrado no Artigo II (3) da Convenção da Organização da União Africana sobre os Aspectos Específicos dos Problemas dos Refugiados em África $(1969){ }^{10}$. (TRINDADE, 2011, p. 292)

Constou do Art. 3 da Convenção das Nações Unidas contra a Tortura de $1984^{11}$. Apesar de seu relativamente recente desenvolvimento histórico, após o fim da Guerra do Vietnã, entre o final da década de 1970 e o início da década de 1980, a não-devolução passou a ser considerada um princípio de direito internacional consuetudinário. (TRINDADE, 2011, p. 292)

Note-se, assim, que os desenvolvimentos mais atuais do princípio do non-refoulement são historicamente muito atuais, especialmente no que concerne à sua importância basilar para o direito internacional dos refugiados. Mais do que uma simples norma comunitária, representa um padrão hermenêutico para toda a referida subdivisão do direito internacional público.

$\mathrm{O}$ princípio do non-refoulement é a base do Direito Internacional dos Refugiados. Significa, essencialmente, que um indivíduo que tenha fundado temor de perseguição não pode ser devolvido ao país onde a sofre, "[...] devendo-lhe ser assegurados meios de sobrevivência digna no país onde será acolhido". (FRIEDRICCH; BENEDETTI, 2016, p. 71)

Apesar desse princípio restar expresso no Art. 33 (1) da Convenção de 1951 e no Art. 22 (8) da Convenção Americana de Direitos Humanos, sua consagração completa ocorreu somente com a denominada Declaração de Cartagena, assinada pelos países das Américas Central e do Sul, em 1984. (FRIEDRICCH; BENEDETTI, 2016, p. 71-72)

Referida convenção surgiu de um colóquio realizado entre os países latino-americanos, que resultou em alguns enunciados, especialmente relacionados à Convenção de Genebra de 1951 . Sua natureza, inicialmente consuetudinária e interpretativa, não impediu sua incorporação como tratado internacional.

Assim, o princípio da não-devolução representa a base valorativa dos atos jurídicos que se voltam a impedir que um determinado Estado devolva um indivíduo que se encontra sob sua jurisdição, em busca de refúgio: “[...] trata-se de coibir a repulsa de um Estado à presença do refugiado em seu território". (PEREIRA, 2014, p. 25).

Também inibe o descaso contra os que solicitam proteção internacional, e visa coibir as tentativas voltadas a determinar a saída compulsória do estrangeiro do território no qual pede refúgio, e deve ser cumprido por todos os países que ratificaram os tratados relacionados ao tema, por força do princípio do pacta sunt servanda. (PEREIRA, 2014, p. 25).

em virtude da sua raça, da sua religião, da sua nacionalidade, do grupo social a que pertence ou das suas opiniões políticas" (ONU, 1951, n.p.).

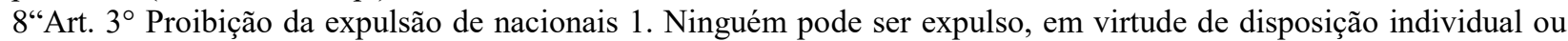
colectiva, do território do Estado de que for cidadão. 2. Ninguém pode ser privado do direito de entrar no território do Estado de que for cidadão" (CE, 1950, n.p.).

9“Art. 22. [...] 8. Em nenhum caso o estrangeiro pode ser expulso ou entregue a outro país, seja ou não de origem, onde seu direito à vida ou à liberdade pessoal esteja em risco de violação por causa da sua raça, nacionalidade, religião, condição social ou de suas opiniões políticas" (OEA, 1969, n.p.).

10“Art. II. 3 - Ninguém pode ser submetido por um Estado-Membro a medidas tais como a recusa de admissão na fronteira, o refoulement ou a expulsão que o obriguem a voltar ou a residir num território onde a sua vida, a sua integridade física ou a sua liberdade estejam ameaçadas pelas razões enumeradas no artigo 1, parágrafos 1 e 2" (OUA, 1969 , n.p.).

11“Art. $3^{\circ}$. 1. Nenhum Estado Parte procederá à expulsão, devolução ou extradição de uma pessoa para outro Estado quando houver razões substanciais para crer que a mesma corre perigo de ali ser submetida a tortura" (ONU, 1984, n.p.). 
Além disso, por se encontrar no âmbito internacional, deve ser aplicado para além das regras de direito interno de cada país. Assim, a vedação à expulsão abrange a proibição do ente estatal. Trata-se, assim, da "[...] primeira garantia conferida ao solicitante de refúgio, assim compreendido pelos instrumentos internacionais" (PEREIRA, 2014, p. 25-26).

A violação desse princípio ocorre no momento da entrada irregular de pessoas em um território nacional, ainda que se encontrem apenas nas fronteiras. Em decorrência das migrações em massa, as violações a esse princípio são constantes, especialmente nos países mais desenvolvidos, ou que "exercem maior protagonismo internacional" (PEREIRA, 2014, p. 26).

A garantia incide antes mesmo da análise do pedido de refúgio do solicitante, de modo que nem a falta de documentos, nem a entrada ilegal do requerente, nem o indeferimento do pleito de status de refugiado podem servir de argumento para sua devolução ou para sua deportação (PEREIRA, 2014, p. 26).

Assim, de modo a que não seja prejudicado o princípio, as autoridades imigratórias devem avaliar as condições de chegada e do país de origem do solicitante. Nesse sentido é que se encontra o Art. $8^{\circ}$ da Lei 9.474 de $1997^{12}$ (PEREIRA, 2014, p. 26), ao determinar que a solicitação de refúgio não pode ser prejudicada pela "entrada irregular no território nacional".

Ocorre que a Declaração de Cartagena, que completou trinta anos em 2014, tem a natureza jurídica original de soft law (não vinculante), podendo ser considerada posteriormente - pela adesão dos Estados latino-americanos - como parte do costume regional latino-americano de proteção de refugiados (RAMOS, 2016, p. 91).

Desse modo, os agentes estatais e seus delegatários nas zonas de fronteira devem impedir o refoulement do estrangeiro solicitante, mesmo que este ingresse no país ilegalmente, de acordo com o que determina o Art. 31 da Convenção de $1951^{13}$, ao impedir a aplicação de penalidade resultante da entrada irregular (RAMOS, 2016, p. 103).

O princípio abarca o solicitante de refúgio (refugee seeker). Vários países vem criando campos de internamento de solicitantes, que lá permanecem até que a decisão final. No Brasil, há proibição do refoulement se existir risco à vida, liberdade e integridade física do indivíduo, nos termos do artigo 32 da Lei n. 9.474 de $1997^{14}$. (RAMOS, 2016, p. 104).

Mesmo que o refúgio não seja outorgado, o indivídou não pode ser enviado ao território no qual possa sofrer atentado à sua liberdade, vida e integridade física em geral. Dessa forma, as autoridades brasileiras não podem promover a saída compulsória do estrangeiro que possa ameaçar tais direitos (RAMOS, 2016, p. 104).

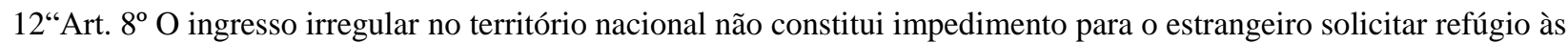
autoridades competentes” (BRASIL, 1997, n.p.).

13“Art. 31 - Refugiados em situação irregular no país de refúgio 1. Os Estados Contratantes não aplicarão sanções penais em virtude da sua entrada ou permanência irregulares, aos refugiados que, chegando diretamente do território no qual sua vida ou sua liberdade estava ameaçada no sentido previsto pelo art. $1^{\circ}$, cheguem ou se encontrem no seu território sem autorização, contanto que se apresentem sem demora às autoridades e lhes exponham razões aceitáveis para a sua entrada ou presença irregulares. 2. Os Estados Contratantes não aplicarão aos deslocamentos de tais refugiados outras restrições que não as necessárias; essas restrições serão aplicadas somente enquanto o estatuto desses refugiados no país de refúgio não houver sido regularizado ou eles não houverem obtido admissão em outro país. À vista desta última admissão os Estados Contratantes concederão a esses refugiados um prazo razoável, assim como todas as facilidades necessárias" (ONU, 1951, n.p.).

14“Art. 32. No caso de recusa definitiva de refúgio, ficará o solicitante sujeito à legislação de estrangeiros, não devendo ocorrer sua transferência para o seu país de nacionalidade ou de residência habitual, enquanto permanecerem as circunstâncias que põem em risco sua vida, integridade física e liberdade, salvo nas situações determinadas nos incisos III e IV do art. $3^{\circ}$ desta Lei” (BRASIL, 1997, n.p.). 
O princípio do non-refoulement incide até mesmo na fase anterior ao deferimento do pedido de refúgio, no sentido de impedir a expulsão daquele que pleiteia o status de refugiado, situação que corrobora a sua natureza de jus cogens e, via de consequência, seu caráter absolutamente vinculante.

Trata-se, portanto, de interpretação justificável, pois o Direito Internacional dos Refugiados tem que o status de refugiado é a condição objetiva do país de origem, não o reconhecimento desse status pelo Estado de acolhida. Assim, o reconhecimento do status de refugiado é declaratório, não constitutivo (RAMOS; RODRIGUES; ALMEIDA, 2011, p. 173).

Não bastasse, em face do princípio do non-refoulement, há uma solução subsidiária para os casos de indeferimento do pedido de refúgio ou de ameaça ao refugiado no país de acolhimento, qual seja, o denominado reassentamento em um terceiro país, de conformidade com os Arts. 45 e 46 da Lei $9.474^{15}$ (RAMOS; RODRIGUES; ALMEIDA, 2011, p. 181).

Desse modo, demonstra-se que, tanto em decorrência de disposições expressas, quanto como consequência das ampliações interpretativas permitidas pelo referido princípio, o nonrefloulement tem inegável natureza de jus cogens, enquadrando-se no conceito firmado pela Declaração de Viena sobre o Direito dos Tratados.

\subsection{O princípio do non-refulement como norma de jus cogens}

O jus cogens compreende, em uma conceituação simplista, aquelas normas que representam as bases jurídicas do direito internacional, tornando-se praticamente imodificáveis e blindadas em relação à derrogação e a retrocessos de qualquer espécie. São as denominadas normas imperativas de Direito Internacional geral.

$\mathrm{Na}$ atual fase do Direito Internacional, notadamente no que tange aos direitos humanos, há um "consenso" quanto a sua veiculação normativa em favor dos direitos humanos. "Valores morais e universais mínimos são assimilados em toda parte, a despeito da convivência com realidades culturais diferentes da cultura ocidental" (BONIFÁCIO, 2008, p. 196-197).

A esse conjunto restrito de normas, costumes e princípios gerais de direito internacional, que demonstram imperatividade e aplicabilidade, dá-se o nome de jus cogens (BONIFÁCIO, 2008, p. 99). São, nesse sentido, as normas de maior hierarquia no sistema jurídico internacional.

A sedimentação dessas normas é necessária para a efetivação do direito internacional dos direitos humanos, pois, sem que existam obrigações erga omnes de proteção, pouco se avança na luta contra o poder arbitrário e a barbárie (TRINDADE, 1999, p. 419). Formam um conjunto de fontes jurídicas às quais assiste poder vinculante (CALIL, 2009, p. 190).

Trata-se, portanto, das verdadeiras bases hermenêuticas desse ramo do direito. Desse modo, influenciam tanto o direito internacional público comum, quanto o direito internacional dos direitos humanos, o direito internacional humanitário e o direito internacional dos refugiados.

Diante disso, enquanto um tratado "comum" pode violar o direito internacional de diversas maneiras, sem que isso resulte em sua invalidade, no contexto do jus cogens, protege-se de tal maneira o interesse da comunidade, que a invalidação do pacto passa a ser o único resultado aceitável. (FARMER, 2008, p. 30)

15“Art. 45. O reassentamento de refugiados em outros países deve ser caracterizado, sempre que possível, pelo caráter voluntário. Art. 46. O reassentamento de refugiados no Brasil se efetuará de forma planificada e com a participação coordenada dos órgãos estatais e, quando possível, de organizações não-governamentais, identificando áreas de cooperação e de determinação de responsabilidades" (BRASIL, 1997, n.p.). 
O termo jus cogens sugriu na Convenção de Viena sobre Direito dos Tratados de 1969, especificamente em seus Arts. 53 e $64^{16}$, que determinam a nulidade de qualquer tratado que conflite com uma norma imperativa de dieito internacional geral, que não pode ser retroceder ou ser derrogada.

Tomando-se em conta a normatividade do jus cogens, pode-se concluir que, em termos globais, a mera participação no seio da ONU é suficiente para que o Estado seja obrigado a abdicar do discurso da soberania inflexível, reconhecendo como válidos os atos internacionais de controle da efetivação dos direitos humanos (RAMOS, 2002, p. 150).

Tratam-se de normas essenciais à sedimentação e à concretização das disposições do direito internacional dos direitos humanos e, via de consequência, do direito internacional dos refugiados, especialmente em decorrência da sistemática normativa que une essas subdivisões do direito internacional público.

Durante o processo preparatório para as Conferências do México (2004), de San José de Costa Rica (12-13 de agosto de 2004), de Brasília (26-27 de agosto de 2004) e Cartagena das Índias (16-17 de setembro de 2004), foram reconhecidos três pontos de importância capital para a proteção do ser humano (RAMOS; RODRIGUES; ALMEIDA, 2011, p. 78).

São eles: a convergência entre as três vertentes da proteção internacional da pessoa humana; a centralidade e a relevância dos princípios gerais de direito; e o caráter de jus cogens do princípio do non-refoulement, por ser um "verdadeiro pilar de todo o Direito Internacional dos Refugiados" (RAMOS; RODRIGUES; ALMEIDA, 2011, p. 78).

Além disso, o princípio do non-refoulement pode ser complementado, em aplicação simultânea, por qualquer norrma jurídica internacional que se relacione ao direito internacional dos direitos humanos, ao direito internacional humanitário ou ao direito internacional dos refugiados.

Até porque, diante das novas ameaças aos direitos humanos em várias partes do mundo, não se pode mais invocar a vacatio legis para deixar de proteger as vítimas. Por isso é que a doutrina e a prática contemporâneas admitem a aplicação simultânea ou concomitante de normas de proteção de qualquer das três vertentes (TRINDADE, 2007, p. 287).

Não bastasse, a Declaração de Cartagena sobre os Refugiados, de 1984, fez referência ao princípio da não-repulsão, dando-o natureza de jus $\operatorname{cogens}^{17}$, caracterização que encontrou apoio na doutrina contemporânea. Trata-se de uma expressão da razão da humanidade, impondo limites à razão de Estado (TRINDADE, 2011, p. 292)

O non-refoulement é a espinha dorsal do sistema legal de refugiados, não admitindo disposição contrária, integrandoo, assim, o jus cogens. Em 1980, na resolução n. 19 (XXXI) sobre o abrigo temporário, o ACNUR considerou necessário observar o princípio de não repulsão "em todas as situações de grande fluxo de refugiados". (TRINDADE, 2011, p. 293)

16“Art. 53. É nulo um tratado que, no momento de sua conclusão, conflite com uma norma imperativa de Direito Internacional geral. Para os fins da presente Convenção, uma norma imperativa de Direito Internacional geral é uma norma aceita e reconhecida pela comunidade internacional dos Estados como um todo, como norma da qual nenhuma derrogação é permitida e que só pode ser modificada por norma ulterior de Direito Internacional geral da mesma natureza. [...] Art. 64. Se sobrevier uma nova norma imperativa de Direito Internacional geral, qualquer tratado existente que estiver em conflito com essa norma torna-se nulo e extingue-se" (ONU, 1969, n.p.).

17“'O Colóquio adotou, deste modo, as seguintes conclusões: [...] Quinta - Reiterar a importância e a significação do princípio de non-refoulement (incluindo a proibição da rejeição nas fronteiras), como pedra angular da proteção internacional dos refugiados. Este princípio imperativo respeitante aos refugiados, deve reconhecer-se e respeitar-se no estado atual do direito internacional, como um princípio de jus cogens" (COLÓQUIO, 1984, n.p.). 
No mesmo sentido, o Comitê de Direitos Humanos, sob o Pacto Internacional sobre Direitos Civis e Políticos das Nações Unidas, entendeu em sucessivos casos de possibilidade ou ameaça de extradição, compreendendo, portanto, o caráter de jus cogens da proibição de maustratos e tortura, mesmo que provável ou potencial. (TRINDADE, 2011, p. 297)

$\mathrm{O}$ alcance do princípio de não-repulsão foi estendido, tanto ratione personae como ratione materiae, alcançando o simples risco de se submeter alguém à tortura ou ao tratamento cruel, desumano ou degradante, tornando essa proibição absoluta. Confirma-se, assim, que o referido princípio se encontra no domínio do jus cogens (TRINDADE, 2011, p. 297-298).

Seu cariz preventivo, junto à possibilidade de aplicação simultânea de outras normas de direito internacional, apenas corroboram seu caráter de norma imperativa de Direito Internacional geral, blindando-o no que concerne a qualquer modificação que possa representar retrocesso.

Nesse sentido, sua integração às normas de jus cogens, faz com que o princípio do nonrefoulement adentre o rol dos valores mais essenciais da comunidade internacional, passando, dessa maneira, a ser um direito que não pode ser negociado ou derrogado por qualquer acordo internacional (FRIEDRICCH; BENEDETTI, 2016, p. 72).

Trata-se da mais importante ferramenta na proteção aos refugiados, pois os coloca a salvo da devolução para uma zona de perigo à sua vida, bem como promove acesso a um procedimento de reconhecimento de seu status, oportunizando, assim, a reconstrução de sua vida e de seus direitos (FRIEDRICCH; BENEDETTI, 2016, p. 72).

$\mathrm{O}$ princípio do non-refoulement foi reconhecido como jus cogens não apenas pela Declaração de Cartagena, como pelo próprio ACNUR ${ }^{18}$. Esse reconhecimento, para além da impossibilidade de derrogação, impede a existência de qualquer limite à sua aplicação, inclusive aqueles constantes da própria Convenção de Genebra de 1951.

\subsection{A (in)existência de exceções ao non-refoulement}

A norma contida no Art. 33 (1) da Convenção de Genebra de 1951, caso seja aplicada de forma estrita, de acordo com sua mera exegese, sem a devida filtragem interpretativa pressuposta para a incidência das normas componentes do jus cogens, poderia até mesmo prejudicar o requerente do status de refugiado.

Isso porque a aplicação desse princípio pode oferecer desvantagens àquele que pleiteia o refúgio, pois o princípio do non-refoulement passa a exigir do órgão judicial um escrutínio mais estrito acerca de eventual falta de preenchimento de algum dos pressupostos necessários para a concessão de refúgio(RAMOS; RODRIGUES; ALMEIDA, 2011, p. 35).

Ocorre que somente constatada a inexistência de fundamento algum é que o Judiciário apreciar poderia negar o refúgio, preservando o instituto de abusos. Isso porque a falta de controle judicial da ato concessivo de refúgio pode resultar na "erosão da credibilidade do refúgio" (RAMOS; RODRIGUES; ALMEIDA, 2011, p. 35).

A revisão deve ser regrada e estrita, em respeito ao princípio do non-refoulement. Deve, porém, ser feita sob o paradigma do pro homine. Assim, a negativa do refúgio deve ser fundamentada pelo Supremo Tribunal Federal, que deverá expor, estreme de dúvidas, a ausência de algum dos requisitos (RAMOS; RODRIGUES; ALMEIDA, 2011, p. 39).

180 ACNUR reconheceu o caráter de jus cogens do princípio da não repulsão, incluindo-se a não-recusa na fronteira, por ser a pedra angular do direito internacional dos refugiados, que confirma o compromisso dos países latinoamericanos de manter fronteiras abertas para garantir a segurança daqueles que necessitm da proteção internacional. (ACNUR, 2011, p 355). 
No mesmo sentido, há exceções ao princípio da não-repulsão, constantes do Art. 33 (2) da Convenção de 1951, que se relacionam à segurança nacional, à condenação definitiva por infração penal grave, ou o fato de constituir ameaça para a comunidade ${ }^{19}$. Ocorre que, entendido o non-refoulement como norma de jus cogens, essas barreiras restam superadas.

A não-devolução é, além de um princípio básico do Direito Internacional dos Refugiados, uma norma peremptória do Direito Internacional dos Direitos Humanos. Sua reiteração em vários instrumentos do direito internacional, desde a Conferência de Paz de Haia de 1899, até os dias de hoje, coloca-o ao lado da cláusula Martens (TRINDADE, 2011, p. 239).

Seu caráter de jus cogens o coloca acima das considerações políticas de ambos os estados e dos órgãos políticos das organizações internacionais, fazendo com que o indíviduo se encontre acima delas na ordem de importância da justiça internacional, limitando a soberania do estado em favor da integridade e do bem-estar da pessoa (TRINDADE, 2011, p. 298).

Corresponde, também, à manifestação de uma visão cada vez mais antropocêntrica do direito internacional contemporâneo, a ilustrar a intensificação das interrelações convergentes dos aspectos da protecção dos direitos da pessoa humana, voltada à sua proteção nos níveis de regulação, interpretação e operação (TRINDADE, 2011, p. 298-308)

O princípio de não-repulsão revela uma dimensão preventiva, que se volta a evitar o mera risco de tortura, crueldade, tratamento inumano ou degradante, resultante de extradição, remoção ou expulsão (TRINDADE, 2011, p. 294-297). Desse modo, torna-se ainda mais difícil, mesmo com o indeferimento do pedido de refúgio, proceder à expulsão do requerente.

Aliás, se essas excepções aos princípios forem circunstâncias verdadeiramente excepcionais, a única maneira na qual princípio poderia ser verdadeiramente aplicado seria permitir que o requerente de asilo permenecesse no território do Estado até que sua condição de refugiado fosse determinada (GALINDO VÉLEZ, 2011, p.182).

O Estado resta obrigado a conceder asilo, mesmo que temporário, sem que isso implique no dever de de aceita-lo por mais tempo do que o necessário para determinar seu status de refugiado ou para encontrar uma solução durável (GALINDO VÉLEZ, 2011, p.182). No mesmo sentido, caem por terra as exceções do Art. 33 (2) da Convenção de Genebra de 1951.

Isso porque, senon-refoulementtiver realmente obtido o status de norma de jus cogens, passando a existir além do regime de tratado, substituindo o consentimento do Estado, opera absoluta e incondicionalmente. Assim, as exceções previstas no Art. 33(2), da Convenção de 1951 devem ser colcoados em causa (FARMER, 2008, p. 22).

Essas exceções, com seus baixos limiares de aplicação, têm grande potencial de minar a proteção aos refugiados e permitir que os Estados violem normas fundamentais de proteção. Assim, tais exceções devem ser limitadas para preservar o caráter fundamental da não-repulsão e a integridade dos direitos subjacentes (FARMER, 2008, p. 23).

O status de jus cogens do non-refoulement conflita com a Própria Convençãço de 1951, pois, nos termos dos Arts. 53 e 62 da Convenção de Viena sobre o Direito dos Tratados, qualquer convenção que com ele conflite deve ser considerada nula. As exceções do Art. 33 (2) devem ser limitadas para preservar sua condição de norma cogente (FARMER, 2008, p. 28).

Isso porque as exceções constam de normas abstratas, de modo que os os Estados signatários podem estabelecer regimes que virtualmente evisceram a própria norma, especialmente

19“Art. 33 - Proibição de expulsão ou de rechaço. [...] 2. O benefício da presente disposição não poderá, todavia, ser invocado por um refugiado que por motivos sérios seja considerado um perigo para a segurança do país no qual ele se encontre ou que, tendo sido condenado definitivamente por crime ou delito particularmente grave, constitui ameaça para a comunidade do referido país" (ONU, 1951, n.p.). 
no que conconerne à exceção de segurança nacional, que permite construir políticas antiterroristas de grande envergadura (FARMER, 2008, p. 28).

A aplicação excessiva das exceções ao não-refoulement deve ser proibida, de modo a impedir a regionalização da norma, especialmente em decorrência das políticas antiterroristas emergentes nos EUA e na Europa (FARMER, 2008, p. 30). Conclui-se, assim, que a natureza de jus cogens do non-refoulement faz com que sua incidência seja, praticamente, absoluta.

\section{CONSIDERAÇÕES FINAIS}

O direito internacional dos refugiados, como resultado de seu progresso teórico e histórico, passou a ter principiologia própria, contudo, dentro do direito internacional público. Seus desenvolvimentos, porém, são historicamente recentes, e resultam das consequências dos grandes conflitos armados.

Desde duas origens, contudo, seus princípios demonstram características de jus cogens. Dentre as tentativas de institucionalização do direito internacional dos refugiados, encontram-se o primeiro Alto Comissariado, surgido a partir da Liga das Nações eo Escritório Nansen, a promover, ainda, uma abordagem coletiva e geral da questão.

Com os fluxos migratórios resultantes da Segunda Guerra Mundial, o padrão de tratamento foi modificado, do coletivo e geral para o individual. Logo após a criação da Organização das Nações Unidas, surgiu o ACNUR, cujas diretrizes passaram a ser ditadas pela Convenção de Genebra sobre os direitos dos refugiados de 1951 que, por sua vez, estabeleceu o conceito de refugiado sob um marco temporal limitado.

Mesmo após a queda do marco migratório determinado, as atribuições do ACNUR permaneceram, a corroborar a autonomia princípiológica do direito internacional dos refugiados, que, todavia, não permite o descumprimento dos princípios gerais ou mesmo a Declaração Universal dos Direitos Humanos.

Essa independência hermenêutica parcial não afasta a incidência de princípios específicos do direito internacional dos refugiados, a exemplo do princípio do non-refoulement. Nesse sentido, o conceito de refugiado constante de Declaração de Genebra de 1951 difere dos conceito de asilo e de exílio.

O fato de o princípio do non-refoulement ser uma norma de jus cogens faz com que sejam desnecessárias alterações convencional expressa, bem como determina uma ampliação interpretativa dos conceitos de refúgio e de perseguição. Passa-se a abarcar todos aqueles que demonstrarem o bem fundadotemor de perseguição.

Faz-se necessário somente que a ameaça individual seja inevitável e objetivamente comprovável. Desse modo, o non-refoulement demonstra ser um padrão hermenêutico para o direito internacional dos refugiados. Sua natureza de jus cogens resta corroborada, expressamente, pela Declaração de Cartagena e pelo ACNUR.

Ao ser reconhecida sua natureza de norma imperativa de Direito Internacional geral, enquadra-se no conceito ditado pela Convenção de Viena sobre o Direito dos Tratados, alcançando a maior hierarquia no sistema jurídico internacional, convertendo-se em base hermenêutica desse ramo do direito.

Nesse diapasão, o princípio do non-refoulement pode ser aplicado de maneira conjunta com outras normas do direito internacional dos direitos humanos, do direito internacional humanitário ou do direito internacional dos refugiados, bem como resta blindado no concernente à derrogação e ao retrocesso. 
Além disso, a expulsão do requerente do status de refugiado, mesmo após seu indeferimento, poderia configurar desobediência ao referido princípio. No mesmo sentido, as limitações constantes do Art. 33 (2) da Convenção de 1951 cairiam por terra, em decorrência da incidência quase absoluta do do non-refoulement.

\section{REFERÊNCIAS}

ACNUR. Alto Comissionado das Nações Unidas para os Refugiados. La protección internacional de refugiados en las Américas. Quito: ACNUR, 2011.

ALMEIDA, Guilherme Assis de. Direitos humanos e não violência. 2. ed. São Paulo: Atlas, 2015.

AGAMBEN, Giogio. Mezzi senza fini: note sulla politica. Torino: Bollati Boringhieri, 1996.

ARENDT, Hannah. Origens do totalitarismo: antisemitismo, imperialismo, totalitarismo. São Paulo: Companhia das Letras, 1989.

BONIFÁCIO. Artur Cortez. O Direito Constitucional Internacional e a proteção dos direitos fundamentais. São Paulo: Editora Método, 2008 (Coleção Professor Gilmar Mendes; 8).

BRASIL. Lei 9474. 1997. Disponível em: 〈www.planalto.gov.br〉. Acesso em: 28 out. 2018.

CALIL, Mário Lúcio Garcez. Efetividade dos procedimentos de proteção dos Direitos Humanos: por um microssistema processual internacional. In: CALIL, Mário Lúcio Garcez; OLIVEIRA, Rafael Sérgio Lima; PRADO, Alessandro Martins. (Org.). Constituição e Direitos Humanos: 20 anos da Constituição Federal e 60 anos da Declaração Universal dos Direitos Humanos. Birigui: Boreal, 2009, v. 1.

CE. Conselho da Europa. Convenção Europeia dos Direitos Humanos. 1950. Disponível em: <https://www.echr.coe.int/Documents/Convention_POR.pdf>. Acesso em: 28 out. 2018.

COLÓQUIO de Proteção Internacional dos Refugiados na América Central, México e Panamá: problemas jurídicos e humanitários. Declaração de Cartagena. 1984. Disponível em: $<$ http://www.acnur.org/fileadmin/Documentos/portugues/BD_Legal/Instrumentos_Internacionais /Declaracao_de_Cartagena.pdf>. Acesso em: 28 out. 2018.

CUNHA, Guilherme da. Migrantes e refugiados: marco jurídico e estratégia no limiar do século XXI. In: PINHEIRO, Paulo Sérgio; GUIMARÃES, Samuel Pinheiro (Orgs.). Direitos humanos no século XXI. Brasília: Senado Federal, 2002.

FARMER, Alice. Non-refoulement and jus cogens: limiting anti-terror measures that threaten refugee protection. Georgetown Immigration Law Journal. v. 23, n. 1, p. 1-38, 2008.

FRIEDRICH, Tatyana Scheila; BENEDETTI, Andréa Regina de Morais.A visibilidade dos invisíveis e os princípios de proteção aos refugiados: notas sobre os acontecimentos recentes. In: 
GEDIEL, José Antonio Peres; GODOY, Gabriel Gulano de. (Org.). Refúgio e hospitalidade. Curitiba: Kairós Edições, 2016.

GALINDO VÉLEZ, Francisco. El asilo en América Latina: uso de los sistemas regionales para fortalecer el sistema de protección de refugiados de las Naciones Unidas. In: ACNUR. Alto Comissionado das Nações Unidas para os Refugiados. La protección internacional de refugiados en las Américas. Quito: ACNUR, 2011.

LOESCHER, Gil. Beyond charity: international cooperation and the global refugee crisis. Oxford: Oxford University Press, 1993.

MURILLO GONZÁLEZ, Juan Carlos. El derecho de asilo y la protección de refugiados en el continente americano. In: ACNUR. Alto Comissionado das Nações Unidas para os Refugiados. La protección internacional de refugiados en las Américas. Quito: ACNUR, 2011.

OEA. Organização dos Estados Americanos.Convenção Americana Sobre Direitos Humanos. 1969. Disponível em: <www.planalto.gov.br>. Acesso em: 28 out. 2018.

ONU. Organização das Nações Unidas. Convenção Relativa ao Estatuto dos Refugiados. 1951. Disponível em: <www.planalto.gov.br>. Acesso em: 28 out. 2018.

ONU. Organização das Nações Unidas. Convenção de Viena sobre Direito dos Tratados. 1969. Disponível em: <www.planalto.gov.br>. Acesso em: 28 out. 2018.

ONU. Organização das Nações Unidas. Convenção das Nações Unidas contra a Tortura. 1984. Disponível em: <www.planalto.gov.br〉. Acesso em: 28 out. 2018.

ONU. Organização das Nações Unidas. Declaração Universal dos Direitos Humanos. 1948. Disponível em: <www.panalto.jus.br>. Acesso em: 29 out. 2018.

ONU. Organização das Nações Unidas. Declaração sobre a Eliminação de Todas as Formas de Intolerência e Discriminação Fundadas na Religião ou nas Convicções. 1981. Disponível em: <www.panalto.jus.br>. Acesso em: 29 out. 2018.

ONU. Organização das Nações Unidas. Pacto Internacional dos Direitos Civis e Políticos. 1966. Disponível em: <www.planalto.gov.br>. Acesso em: 28 out. 2018.

OUA. Organização da União Africana.Convenção da Organização da União Africana sobre os Aspectos Específicos dos Problemas dos Refugiados em África. 1969. <http://www.refugiados.net/cid_virtual_bkup/asilo2/2couaapr.html>. Acesso em: 28 out. 2018.

PEREIRA, Gustavo Oliveira de Lima. Direitos humanos e hospitalidade: a proteção internacional para apátridas e refugiados. São Paulo: Atlas, 2014.

RAMOS, André de Carvalho. Teoria geral dos direitos humanos na ordem internacional. 6. ed. São Paulo: Saraiva, 2016. 
RAMOS, André de Carvalho. Processo Internacional dos Direitos Humanos: análise dos sistemas de apuração de violações dos direitos humanos e a implementação das decisões no Brasil. Rio de Janeiro: Renovar, 2002.

RAMOS, André de Carvalho; RODRIGUES, Gilberto; ALMEIRA, Guilherme Assis de Almeida. 60 anos de ACNUR: perspectivas de futuro. São Paulo: Editora CL-A Cultural, 2011.

TRINDADE, Antonio Augusto Cançado. Desafios e conquistas do Direito Internacional dos Direitos Humanos no início do Século XXI. In: MEDEIROS, Antônio Paulo Cachapuz. (Org.) Desafios do Direito Internacional Contemporâneo. Brasília: Funag, 2007.

TRINDADE, Antonio Augusto Cançado. Aproximaciones y convergencias revisitadas: diez años de interacción entre el derecho internacional de los derechos humanos, el derecho internacional de los refugiados, y el derecho internacional humanitário (De Cartagena/1984 a San José/1994 y México/2004). In: ACNUR. Alto Comissionado das Nações Unidas para os Refugiados. La protección internacional de refugiados en las Américas. Quito: ACNUR, 2011.

TRINDADE, Antonio Augusto Cançado. Tratado de Direito Internacional dos Direitos Humanos. v. II. Porto Alegre: Sergio Antonio Fabris Editor, 1999. 